\title{
Titus Phase Ceramic Vessels from the W. L. Willeford Farm, Upshur County, Texas
}

Timothy K. Perttula

Heritage Research Center, Stephen F. Austin State University

Mark Walters

Heritage Research Center, Stephen F. Austin State University

Follow this and additional works at: https://scholarworks.sfasu.edu/ita

Part of the American Material Culture Commons, Archaeological Anthropology Commons, Environmental Studies Commons, Other American Studies Commons, Other Arts and Humanities Commons, Other History of Art, Architecture, and Archaeology Commons, and the United States History Commons

Tell us how this article helped you.

This Article is brought to you for free and open access by the Center for Regional Heritage Research at SFA ScholarWorks. It has been accepted for inclusion in Index of Texas Archaeology: Open Access Gray Literature from the Lone Star State by an authorized editor of SFA ScholarWorks. For more information, please contact cdsscholarworks@sfasu.edu. 


\section{Titus Phase Ceramic Vessels from the W. L. Willeford Farm, Upshur County,}

Texas

\section{Creative Commons License}

\section{(c) (1) (9)}

This work is licensed under a Creative Commons Attribution-NonCommercial 4.0 International License 


\section{Titus Phase Ceramic Vessels from the W. L. Willeford Farm, Upshur County, Texas}

\section{Timothy K. Perttula and Mark Walters}

\section{INTRODUCTION AND SITE SETTING}

The W. L. Willeford site (41UR5) is a Late Caddo period Titus phase cemetery of unknown size. It is in the Little Walnut Creek basin, and Little Walnut Creek is a southward-flowing tributary to Little Cypress Creek in the East Texas Pineywoods (Figure 1).

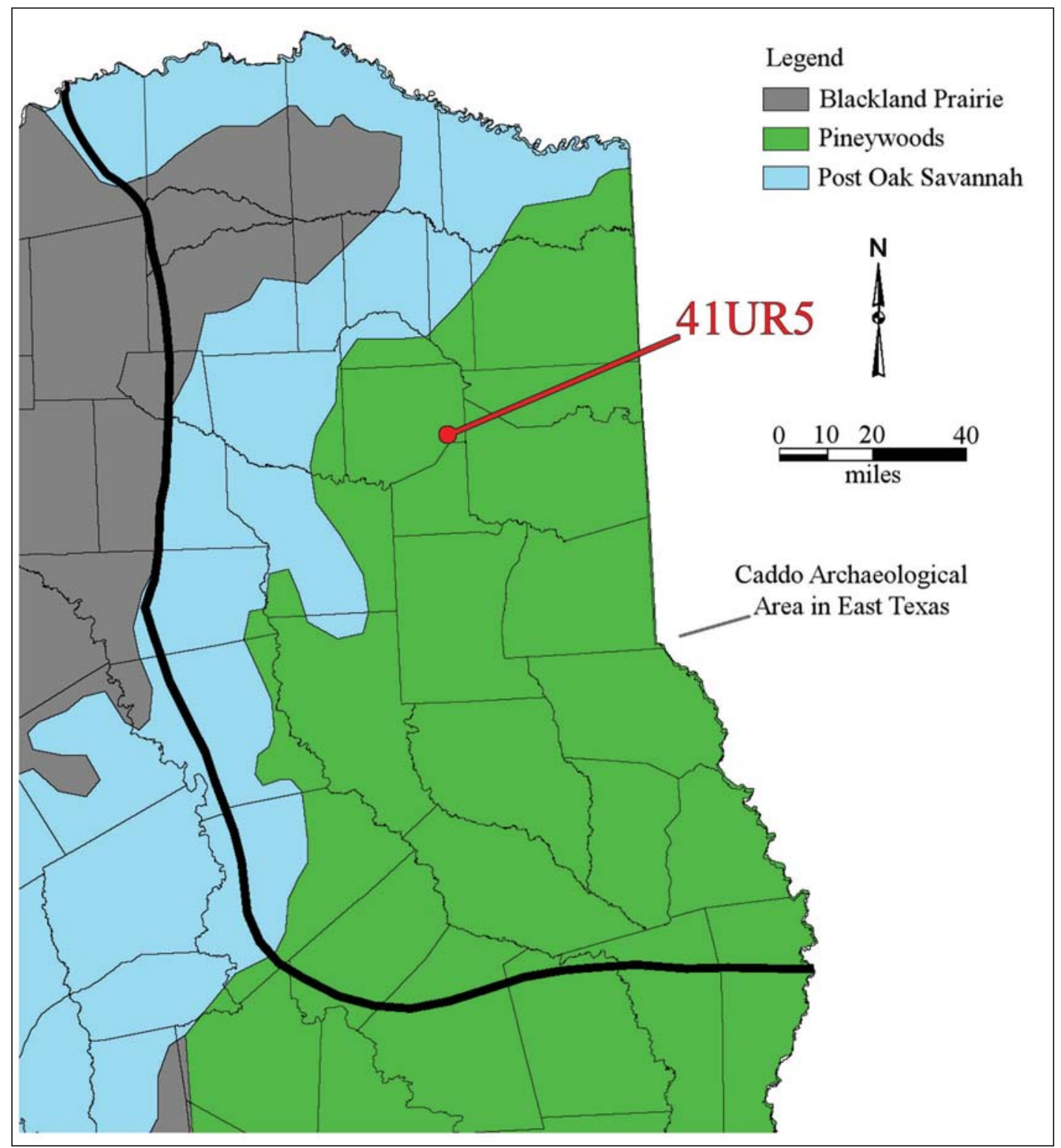

Figure 1. Location of the W. L. Willeford site in East Texas. 
Some time prior to 1930, Caddo vessels had been exposed by erosion at the site, and other vessels were plowed up in 1930. University of Texas (UT) archaeologists led by B. B. Gardner excavated at the site in July 1931, but found no burials. The UT archaeologists purchased Caddo vessels from the landowner, along with three elbow pipes, two celts, and two arrow points. Those vessels $(n=15)$ are documented in the remainder of this article.

During the UT excavations at the W. L. Willeford Farm site, a sizeable assemblage of plain $(\mathrm{n}=110)$ and decorated $(\mathrm{n}=108)$ ceramic sherds were recovered from apparent habitation contexts near to the locations where the burial vessels had been reported. The decorated sherds are from Ripley Engraved and Wilder Engraved vessels $(n=32)$, red-slipped fine wares $(n=6)$ and various utility wares. These are from brushed $(n=28)$ and brushed-punctated ( $\mathrm{n}=3$ ) Bullard Brushed vessels, La Rue Neck Banded jars ( $\mathrm{n}=5)$, as well as sherds from Cass Appliqued $(n=3)$, Belcher Ridged ( $n=1)$, Killough Pinched $(n=1)$, Maydelle Incised $(n=23)$, punctated $(\mathrm{n}=5)$, and incised-punctated $(\mathrm{n}=1)$ vessels. The occurrence of both Cass Appliqued and Belcher Ridged vessel sherds in the assemblage suggests that the site was occupied sometime after ca. A.D. 1500/1550.

\section{Ceramic Vessels}

SITE NAME OR SITE NUMBER: W. L. Willeford Farm

VESSEL NO.: UR5-1

VESSEL FORM: grog

NON-PLASTICS AND PASTE: Carinated bowl

RIM AND LIP FORM: Direct rim and rounded, exterior folded lip

CORE COLOR: $\mathrm{G}$ (fired in a reducing environment and cooled in the open air)

INTERIOR SURFACE COLOR: grayish-brown

EXTERIOR SURFACE COLOR: yellowish-brown; fire clouds on the rim, body, and base

WALL THICKNESS (IN MM): rim, $5.1 \mathrm{~mm}$

INTERIOR SURFACE TREATMENT: smoothed

EXTERIOR SURFACE TREATMENT: burnished

HEIGHT (IN CM): 11.5

ORIFICE DIAMETER (IN CM): 23.7

DIAMETER AT BOTTOM OF RIM OR NECK (IN CM): 23.4

BASE DIAMETER (IN CM) AND SHAPE OF BASE: 8.0; circular and flat

ESTIMATED VOLUME (IN LITERS): 1.6

DECORATION (INCLUDING MOTIF AND ELEMENTS WHEN APPARENT): The rim panel is defined by single upper and lower horizontal engraved lines. On the panel are four horizontal scrolls with rounded 
ends; these are divided by vertical brackets with upper and lower diagonal tick marks (Figure 2). Above and below each of the scrolls are a series of excised pendant triangles.

PIGMENT USE AND LOCATION ON VESSEL: None

TYPE AND VARIETY (IF KNOWN): Ripley Engraved, var. McKinney-Enis Smith (Fields et al. 2014:Table 8.6)

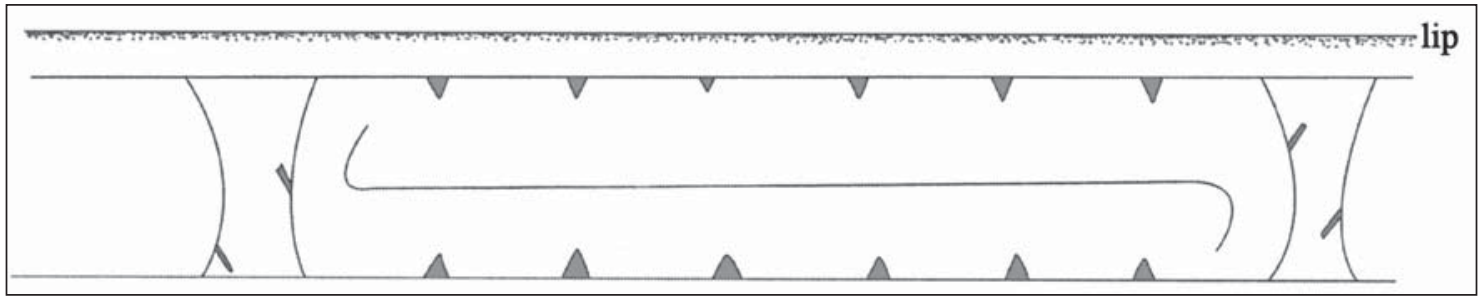

Figure 2. Decorative elements on a Ripley Engraved, var. McKinney-Enis Smith carinated bowl from the W. L. Willeford Farm site.

SITE NAME OR SITE NUMBER: W. L. Willeford Farm

VESSEL NO.: UR5-2

VESSEL FORM: Carinated bowl

NON-PLASTICS AND PASTE: grog

RIM AND LIP FORM: Direct rim and a rounded, exterior folded lip

CORE COLOR: G (fired in a reducing environment and cooled in the open air)

INTERIOR SURFACE COLOR: dark grayish-brown; fire clouds on the rim

EXTERIOR SURFACE COLOR: brown; fire clouds on the lower body and base

WALL THICKNESS (IN MM): rim, 6.4 mm

INTERIOR SURFACE TREATMENT: smoothed

EXTERIOR SURFACE TREATMENT: smoothed

HEIGHT (IN CM): 9.8

ORIFICE DIAMETER (IN CM): 22.0

DIAMETER AT BOTTOM OF RIM OR NECK (IN CM): 21.0

BASE DIAMETER (IN CM) AND SHAPE OF BASE: 8.0; circular and flat

ESTIMATED VOLUME (IN LITERS): 1.3

DECORATION (INCLUDING MOTIF AND ELEMENTS WHEN APPARENT): The rim panel is defined 
by single upper and lower horizontal engraved lines. On the panel are four horizontal scrolls with rounded ends; these are divided by vertical brackets with upper and lower diagonal tick marks (Figure 3). Above and below each of the scrolls are a series of excised pendant triangles. There is also a single horizontal engraved line on the interior of the vessel at the carination.

PIGMENT USE AND LOCATION ON VESSEL: None

TYPE AND VARIETY (IF KNOWN): Ripley Engraved, var. McKinney-Enis Smith (Fields et al. 2014:Table 8.6)

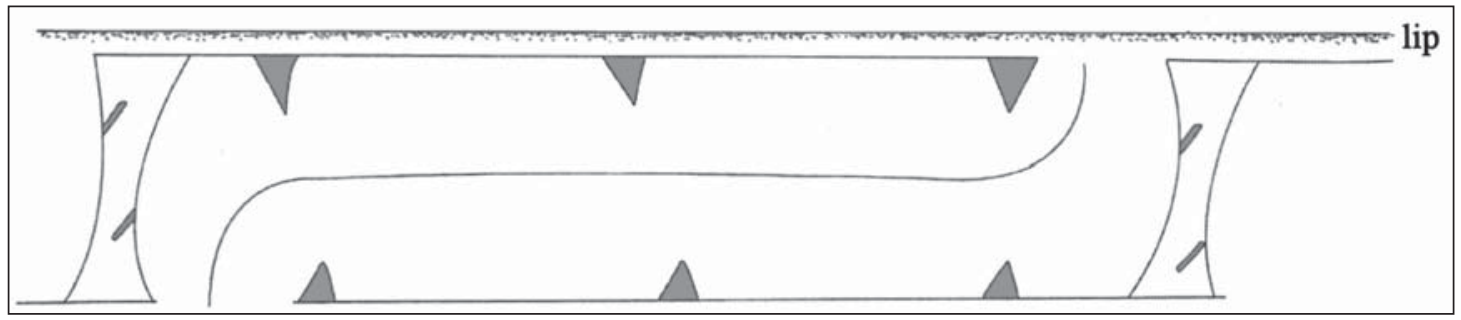

Figure 3. Decorative elements on a Ripley Engraved, var. McKinney-Enis Smith carinated bowl from the W. L. Willeford Farm site.

SITE NAME OR SITE NUMBER: W. L. Willeford Farm

VESSEL NO.: UR5-3

VESSEL FORM: Carinated bowl

NON-PLASTICS AND PASTE: grog

RIM AND LIP FORM: Direct rim and rounded, exterior folded lip

CORE COLOR: $\mathrm{G}$ (fired in a reducing environment and cooled in the open air)

INTERIOR SURFACE COLOR: grayish-brown

EXTERIOR SURFACE COLOR: yellowish-brown; fire clouds on the rim, body, and base

WALL THICKNESS (IN MM): rim, $5.2 \mathrm{~mm}$

INTERIOR SURFACE TREATMENT: smoothed

EXTERIOR SURFACE TREATMENT: burnished

HEIGHT (IN CM): 9.0

ORIFICE DIAMETER (IN CM): 14.6

DIAMETER AT BOTTOM OF RIM OR NECK (IN CM): 14.7

BASE DIAMETER (IN CM) AND SHAPE OF BASE: 5.8; circular and flat

ESTIMATED VOLUME (IN LITERS): 0.8 
DECORATION (INCLUDING MOTIF AND ELEMENTS WHEN APPARENT): The rim panel is defined by single upper and lower horizontal engraved lines with excised pendant triangles. On the panel are four horizontal scrolls with two alternating central circle or diamond elements (Figure 4). The horizontal scrolls end in upper and lower engraved brackets. Both central circle and diamond elements have within them a smaller central diamond element.

PIGMENT USE AND LOCATION ON VESSEL: None

TYPE AND VARIETY (IF KNOWN): Ripley Engraved, var. McKinney

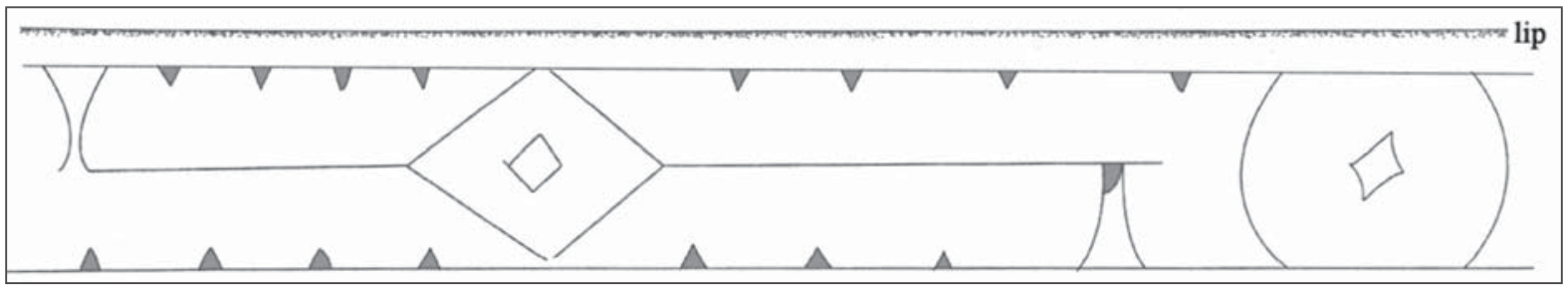

Figure 4. Decorative elements on a Ripley Engraved, var. McKinney carinated bowl from the W. L. Willeford Farm site.

SITE NAME OR SITE NUMBER: W. L. Willeford Farm

VESSEL NO.: UR5-4

VESSEL FORM: Jar

NON-PLASTICS AND PASTE: grog

RIM AND LIP FORM: Everted rim and rounded lip

CORE COLOR: $\mathrm{F}$ (fired in a reducing environment and cooled in the open air)

INTERIOR SURFACE COLOR: yellowish-brown; fire clouds on the rim, body, and base

EXTERIOR SURFACE COLOR: yellowish-brown; fire clouds on the rim, body, and base

WALL THICKNESS (IN MM): rim, $6.0 \mathrm{~mm}$

INTERIOR SURFACE TREATMENT: smoothed

EXTERIOR SURFACE TREATMENT: none

HEIGHT (IN CM): 12.0

ORIFICE DIAMETER (IN CM): 13.8

DIAMETER AT BOTTOM OF RIM OR NECK (IN CM): 13.4

BASE DIAMETER (IN CM) AND SHAPE OF BASE: 7.0; circular and flat

ESTIMATED VOLUME (IN LITERS): 1.0 
DECORATION (INCLUDING MOTIF AND ELEMENTS WHEN APPARENT): The rim has horizontal brushing marks as well as two rows of tool punctations. The top row is below the lip and has been pushed through the brushing (Figure 5). The bottom row is at the top of the vessel body, immediately below the rimbody juncture. The vessel body has six widely-spaced vertical appliqued fillets that extend to within $13 \mathrm{~mm}$ of the base. They divide the vessel body into six plain panels.

PIGMENT USE AND LOCATION ON VESSEL: None

TYPE AND VARIETY (IF KNOWN): Unidentified utility ware

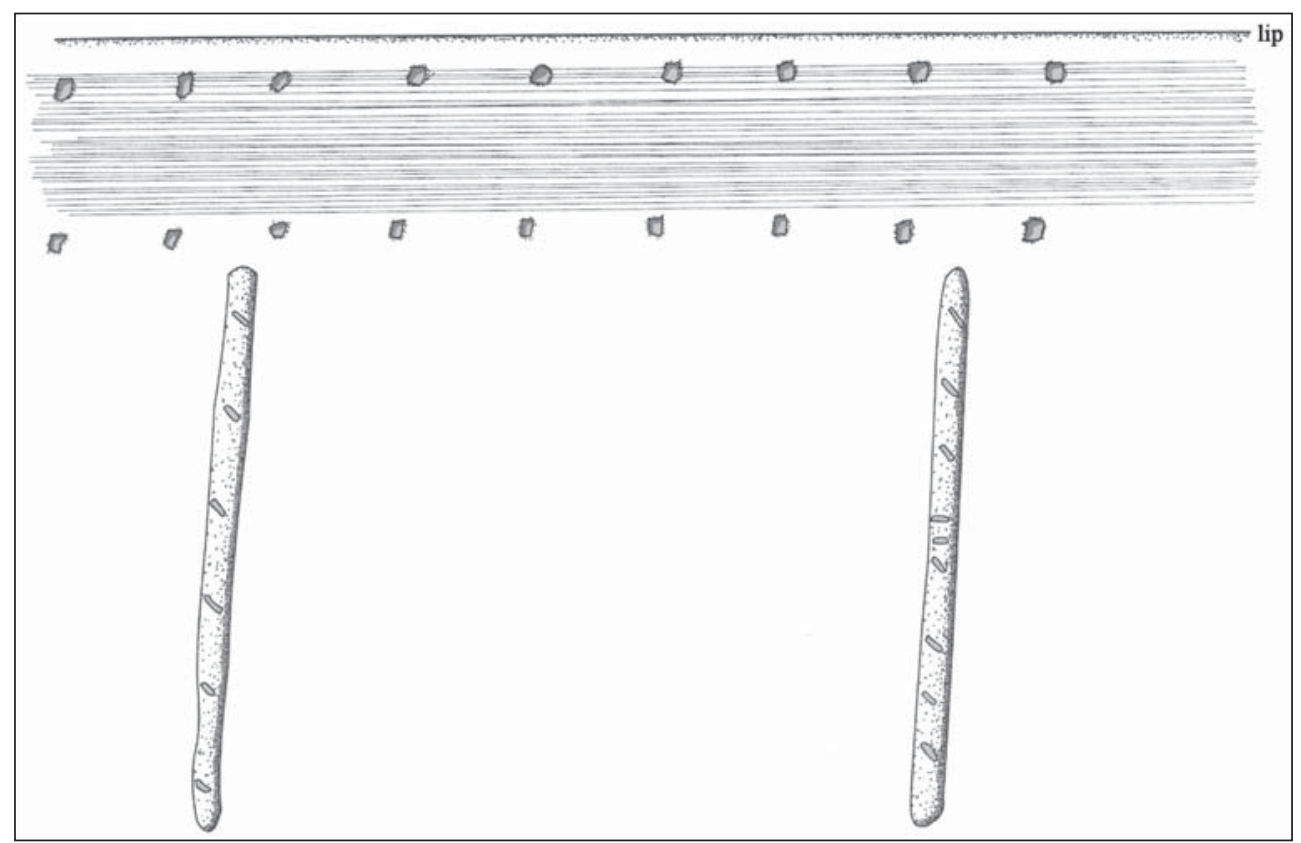

Figure 5. Decorative elements on a Brushed-punctated-appliqued jar from the W. L. Willeford Farm site.

SITE NAME OR SITE NUMBER: W. L. Willeford Farm

VESSEL NO.: UR5-6

VESSEL FORM: Jar

NON-PLASTICS AND PASTE: grog

RIM AND LIP FORM: N/A

CORE COLOR: B (fired and cooled in a reducing environment)

INTERIOR SURFACE COLOR: very dark grayish-brown

EXTERIOR SURFACE COLOR: very dark grayish-brown

WALL THICKNESS (IN MM): body, $6.8 \mathrm{~mm}$

INTERIOR SURFACE TREATMENT: smoothed 
EXTERIOR SURFACE TREATMENT: none

HEIGHT (IN CM): body height, $9.5 \mathrm{~cm}$

ORIFICE DIAMETER (IN CM): 9.1

DIAMETER AT BOTTOM OF RIM OR NECK (IN CM): 9.1

BASE DIAMETER (IN CM) AND SHAPE OF BASE: 6.5; circular and flat

ESTIMATED VOLUME (IN LITERS): N/A

DECORATION (INCLUDING MOTIF AND ELEMENTS WHEN APPARENT): The vessel has four sets of upper and lower hooked arm elements that are composed of appliqued fillets (Figure 6). Above and below the appliqued hooked arms are horizontal appliqued fillets at the top of the vessel body and near the vessel base. The areas between the horizontal and hooked arm appliqued fillets are filled with horizontal to curvilinear brushing marks.

PIGMENT USE AND LOCATION ON VESSEL: None

TYPE AND VARIETY (IF KNOWN): cf. Harleton Appliqued (see Suhm and Jelks 1962:65)

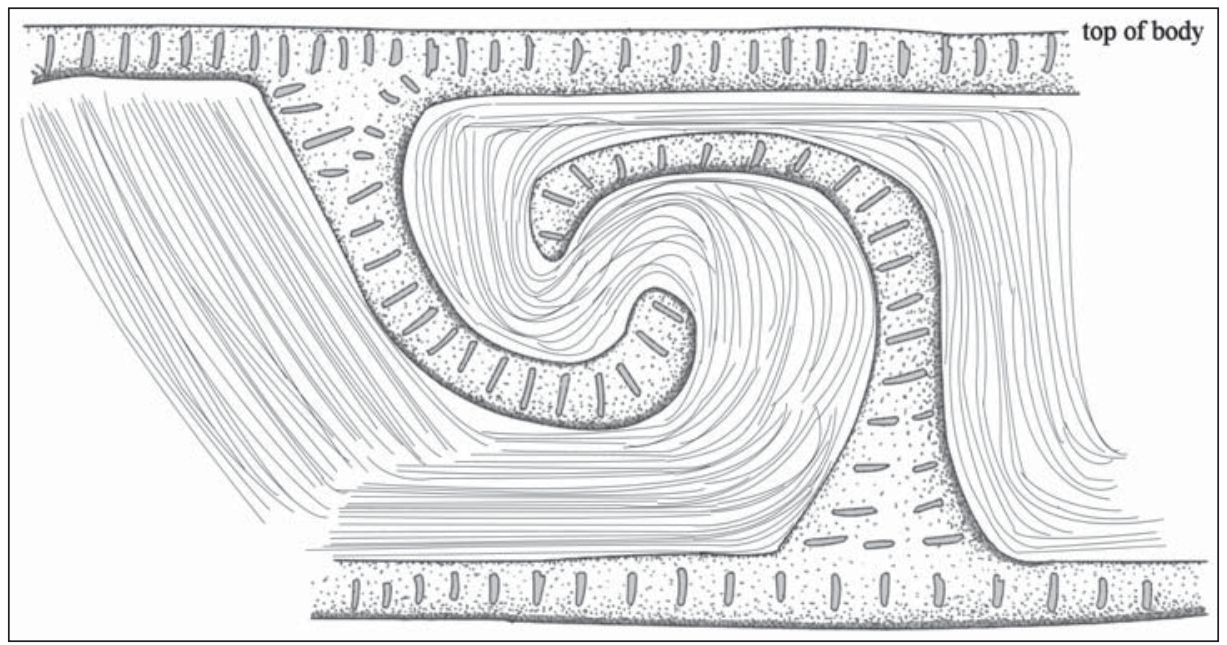

Figure 6. cf. Decorative elements on a Harleton Appliqued jar from the W. L. Willeford Farm site.

SITE NAME OR SITE NUMBER: W. L. Willeford Farm

VESSEL NO.: UR5-7

VESSEL FORM: Bottle with the neck missing

NON-PLASTICS AND PASTE: grog

RIM AND LIP FORM: N/A

CORE COLOR: B (fired and cooled in a reducing environment) 
INTERIOR SURFACE COLOR: very dark grayish-brown

EXTERIOR SURFACE COLOR: black

WALL THICKNESS (IN MM): neck, $6.7 \mathrm{~mm}$

INTERIOR SURFACE TREATMENT: none

EXTERIOR SURFACE TREATMENT: burnished

HEIGHT (IN CM): $8.5 \mathrm{~cm}$, body height

ORIFICE DIAMETER (IN CM): 4.5

DIAMETER AT BOTTOM OF RIM OR NECK (IN CM): 4.5; maximum body diameter is $11.0 \mathrm{~cm}$

BASE DIAMETER (IN CM) AND SHAPE OF BASE: 7.5; circular and rounded

ESTIMATED VOLUME (IN LITERS): N/A

DECORATION (INCLUDING MOTIF AND ELEMENTS WHEN APPARENT): The top of the vessel body has a square zone delimited by a single horizontal engraved line below the bottle neck that is filled with rows of excised punctations (Figure 7). Below the zone of excised punctations are four sets of engraved concentric arches: the upper arc has three lines that arch upwards (and form a square when viewed from above), while the lower part of the set has 14 lines that arc downward and fit under the upper arcing lines; these lines also form a square when viewed from above.

PIGMENT USE AND LOCATION ON VESSEL: None

TYPE AND VARIETY (IF KNOWN): Bailey Engraved

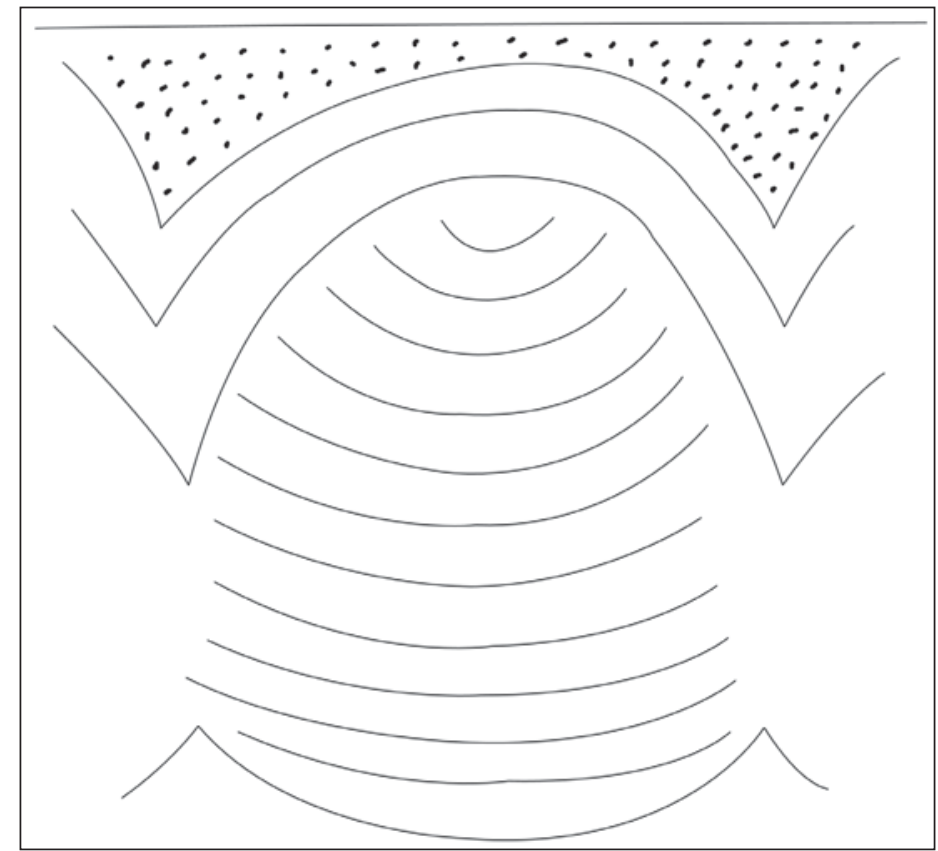

Figure 7. Decorative elements on Bailey Engraved bottle from the W. L. Willeford Farm site. 
SITE NAME OR SITE NUMBER: W. L. Willeford Farm

VESSEL NO.: UR5-8

VESSEL FORM: Jar

NON-PLASTICS AND PASTE: grog

RIM AND LIP FORM: Direct rim and rounded, exterior folded lip

CORE COLOR: B (fired and cooled in a reducing environment)

INTERIOR SURFACE COLOR: very dark grayish-brown

EXTERIOR SURFACE COLOR: very dark grayish-brown; fire clouds on the body

WALL THICKNESS (IN MM): rim, $5.3 \mathrm{~mm}$

INTERIOR SURFACE TREATMENT: smoothed on the rim

EXTERIOR SURFACE TREATMENT: burnished

HEIGHT (IN CM): 8.8

ORIFICE DIAMETER (IN CM): 8.0

DIAMETER AT BOTTOM OF RIM OR NECK (IN CM): 7.8

BASE DIAMETER (IN CM) AND

SHAPE OF BASE: 5.7; circular and flat

ESTIMATED VOLUME (IN LITERS):

0.4

DECORATION (INCLUDING MOTIF AND ELEMENTS WHEN APPARENT): The rim of the vessel has three horizontal engraved lines, two of which have a series of open pendant triangles (Figure 8). At the top of the vessel body are two more

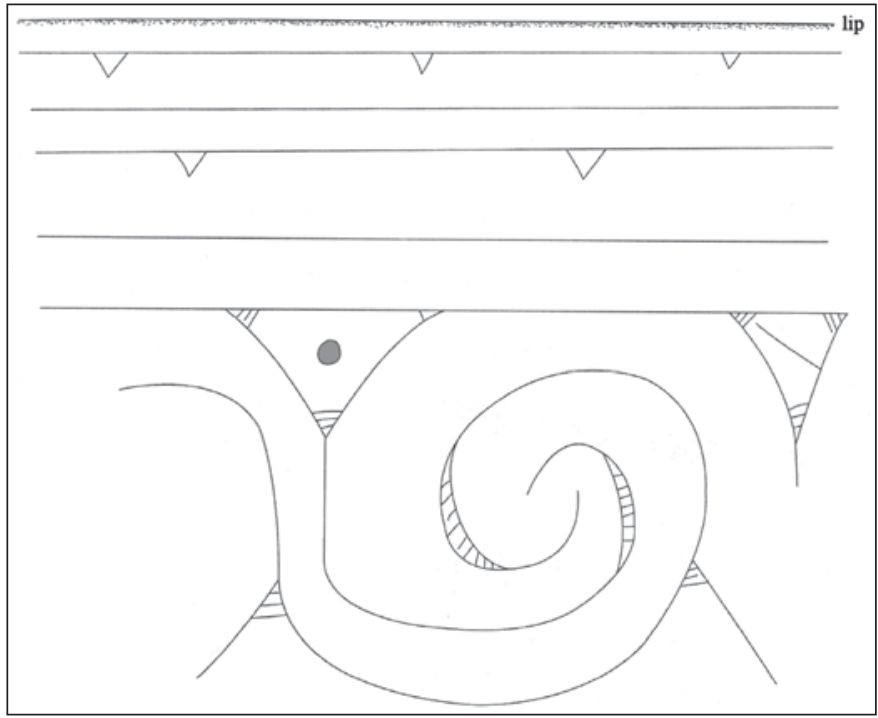

Figure 8. Decorative elements on Wilder Engraved, var. unspecified jar from the W. L. Willeford farm site. horizontal engraved lines, the bottom line with open engraved pendant triangles, as well as upper and lower hooked arm vertical scrolls repeated four times around the body; the scrolls extend to just above the vessel base. There are hatched zones on the scrolls opposite the hooked arms (Figure 8). The scrolls begin at the apex of large pendant triangles with hatched corners; the upper set of large pendant triangles have either a small central excised circle $(n=3)$ or a diagonal line $(n=1)$, while the lower set of large pendant triangles have no inner central elements.

PIGMENT USE AND LOCATION ON VESSEL: red pigment in the engraved lines on the vessel body

TYPE AND VARIETY (IF KNOWN): Wilder Engraved, var. unspecified 
SITE NAME OR SITE NUMBER: W. L. Willeford

VESSEL NO.: UR5-9

VESSEL FORM: Jar

NON-PLASTICS AND PASTE: grog

RIM AND LIP FORM: Everted rim and a rounded lip

CORE COLOR: $\mathrm{G}$ (fired in a reducing environment and cooled in the open air)

INTERIOR SURFACE COLOR: grayish-brown; fire clouds on the rim

EXTERIOR SURFACE COLOR: yellowish-brown; fire clouds on the rim, body, and base

WALL THICKNESS (IN MM): rim, $6.2 \mathrm{~mm}$

INTERIOR SURFACE TREATMENT: smoothed

EXTERIOR SURFACE TREATMENT: none

HEIGHT (IN CM): 7.0

ORIFICE DIAMETER (IN CM): 7.5

DIAMETER AT BOTTOM OF RIM OR NECK (IN CM): 6.8

BASE DIAMETER (IN CM) AND SHAPE OF BASE: 3.0; circular and flat

ESTIMATED VOLUME (IN LITERS): 0.3

DECORATION (INCLUDING MOTIF AND ELEMENTS WHEN APPARENT): The rim of the vessel has four horizontal rows of tool punctations. The vessel body has 26 diagonal incised lines that are pitched from left to right, and extend from the rim-body juncture to just above the base.

PIGMENT USE AND LOCATION ON VESSEL: None

TYPE AND VARIETY (IF KNOWN): Unidentified utility ware

SITE NAME OR SITE NUMBER: W. L. Willeford Farm

VESSEL NO.: UR5-10

VESSEL FORM: Conjoined vessel — a carinated bowl joined to a jar (Figure 9a; see Suhm and Jelks 1962:Plate 78a)

NON-PLASTICS AND PASTE: grog

RIM AND LIP FORM: Direct rim and rounded, exterior folded, lip; the rim is cambered on the interior (represents the body of the carinated bowl that is conjoined with the jar rim) 
CORE COLOR: F (fired in a reducing environment and cooled in the open air)

INTERIOR SURFACE COLOR: reddish-brown; fire clouds on the body

EXTERIOR SURFACE COLOR: reddish-brown; fire clouding on the body and base

WALL THICKNESS (IN MM): rim, 5.9 mm

INTERIOR SURFACE TREATMENT: smoothed

EXTERIOR SURFACE TREATMENT: burnished

HEIGHT (IN CM): 10.8

ORIFICE DIAMETER (IN CM): 10.3

DIAMETER AT BOTTOM OF RIM OR NECK (IN CM): 11.0 (carinated bowl); 8.5 (jar)

BASE DIAMETER (IN CM) AND SHAPE OF BASE: 7.0; circular and rounded

ESTIMATED VOLUME (IN LITERS): 0.7

DECORATION (INCLUDING MOTIF AND ELEMENTS WHEN APPARENT): The carinated bowl section of the conjoined vessel has a series of four alternating half circles and ovals that are divided by vertical excised bars and triangles. The half circles and ovals have either a central vertical line or a triangle element (Figure 9b). The rim also has two $3.6 \mathrm{~mm}$ diameter suspension holes above the excised triangles.

The rim of the conjoined jar has a single horizontal engraved line. The jar body has four meandering vertical scrolls. The upper and lower arms of the scroll begin at the apex of upper and lower pendant triangles (see Figure 9b). The pendant triangles have excised corners.

PIGMENT USE AND LOCATION ON VESSEL: None

TYPE AND VARIETY (IF KNOWN): Wilder Engraved, var. unspecified

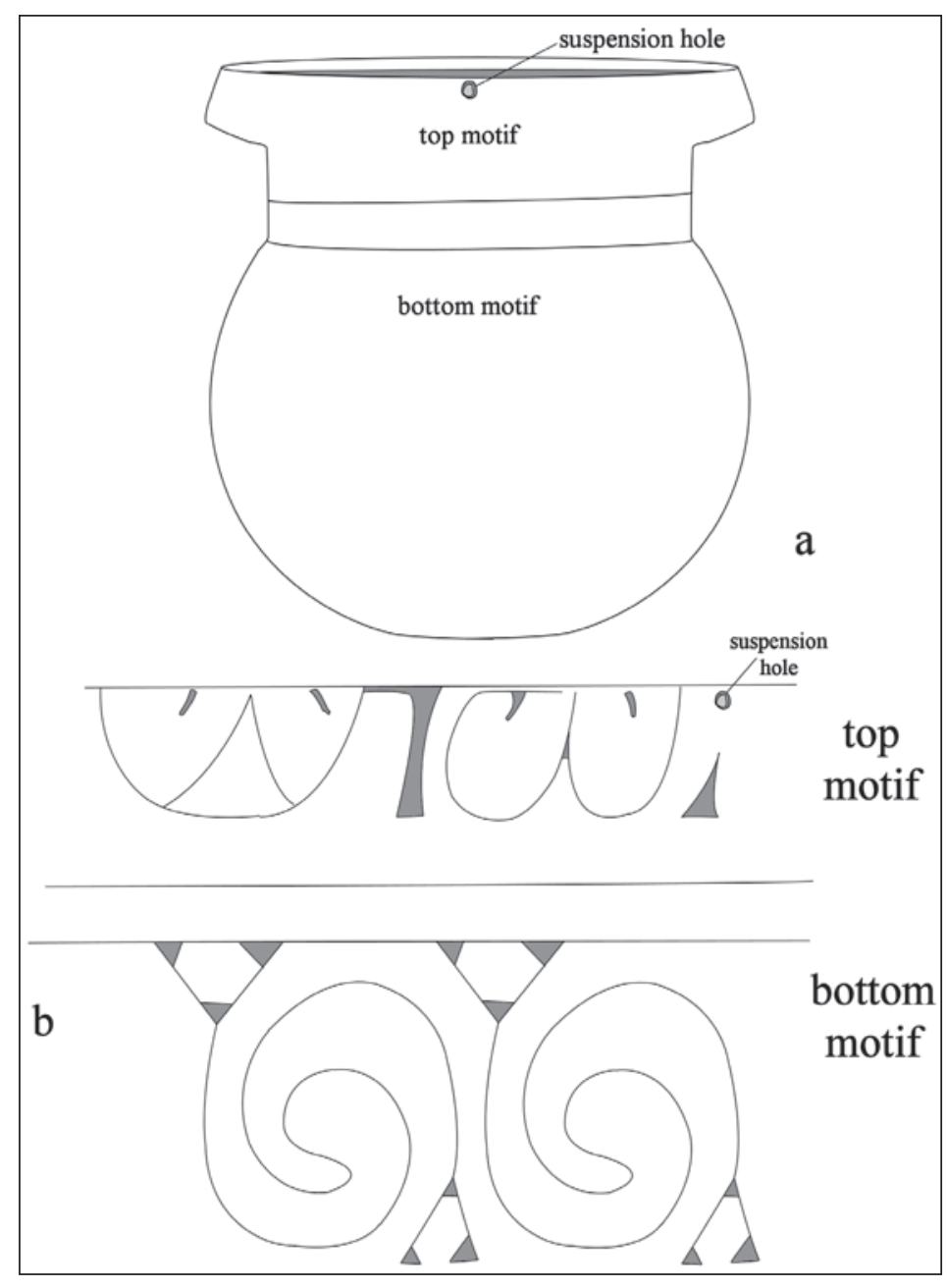

Figure 9. Decorative elements on a conjoined Wilder Engraved, var. unspecified jar and a Ripley Engraved, var. Starkey carinated bowl: a, vessel shape; $b$, decorative elements. 
SITE NAME OR SITE NUMBER: W. L. Willeford Farm

VESSEL NO.: UR5-11

VESSEL FORM: Bowl

NON-PLASTICS AND PASTE: grog

RIM AND LIP FORM: Direct rim and rounded lip

CORE COLOR: B (fired and cooled in a reducing environment)

INTERIOR SURFACE COLOR: grayish-brown

EXTERIOR SURFACE COLOR: grayish-brown; fire clouds on the rim and body

WALL THICKNESS (IN MM): rim, $4.2 \mathrm{~mm}$

INTERIOR SURFACE TREATMENT: smoothed

EXTERIOR SURFACE TREATMENT: burnished

HEIGHT (IN CM): 10.3

ORIFICE DIAMETER (IN CM): 11.7

DIAMETER AT BOTTOM OF RIM OR NECK (IN CM): N/A

BASE DIAMETER (IN CM) AND SHAPE OF BASE: 6.0; circular and flat

ESTIMATED VOLUME (IN LITERS): 0.49

DECORATION (INCLUDING MOTIF AND ELEMENTS WHEN APPARENT): The vessel rim and body is divided into two panels by two sets of three vertical engraved lines. The middle line has linear tick marks. The upper part of the two panels is divided by a single curvilinear line into a lower plain section and an upper section filled with a continuous series of small ovals (Figure 10), what we have dubbed the "fish scale" effect.

PIGMENT USE AND LOCATION ON VESSEL: None

TYPE AND VARIETY

(IF KNOWN): Unidentified fine ware

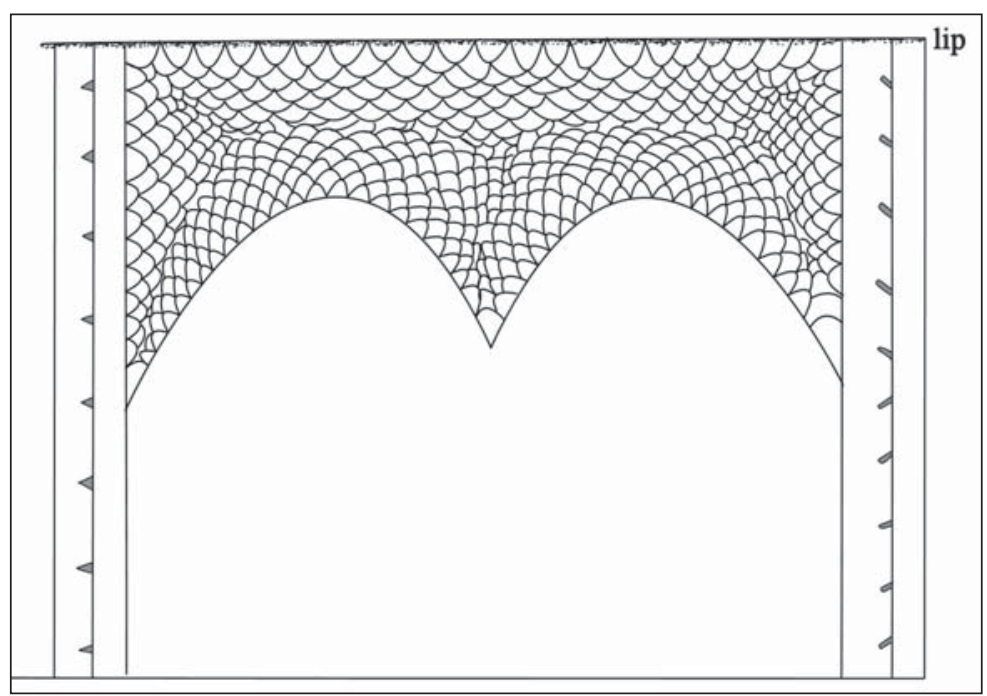

Figure 10. Decorative elements on engraved bowl from the W. L. Willeford Farm site. 
SITE NAME OR SITE NUMBER: W. L. Willeford Farm

VESSEL NO.: UR5-12

VESSEL FORM: Compound bowl

NON-PLASTICS AND PASTE: grog

RIM AND LIP FORM: Everted rim and a rounded lip

CORE COLOR: F (fired in a reducing environment and cooled in the open air)

INTERIOR SURFACE COLOR: reddish-brown

EXTERIOR SURFACE COLOR: reddish-brown; fire clouds on the body and base

WALL THICKNESS (IN MM): rim, $3.5 \mathrm{~mm}$

INTERIOR SURFACE TREATMENT: smoothed on the rim

EXTERIOR SURFACE TREATMENT: smoothed

HEIGHT (IN CM): 6.4

ORIFICE DIAMETER (IN CM): 7.3

DIAMETER AT BOTTOM OF RIM OR NECK (IN CM): 6.0

BASE DIAMETER (IN CM) AND SHAPE OF BASE: 5.8; circular and convex

ESTIMATED VOLUME (IN LITERS): 0.37

DECORATION (INCLUDING MOTIF AND ELEMENTS WHEN APPARENT): The upper panel of the vessel is plain, but the lower panel has a series of unique and idiosyncratic engraved decorative elements (Figure 11). These elements include hooked arms, meandering scrolls, curvilinear lines, vertical brackets, vertical and diagonal lines, and a single oval. There is no clear repetition of the decorative elements, suggesting this vessel was decorated by a novice.

PIGMENT USE AND LOCATION ON VESSEL: None

TYPE AND VARIETY (IF KNOWN): Unidentified fine ware

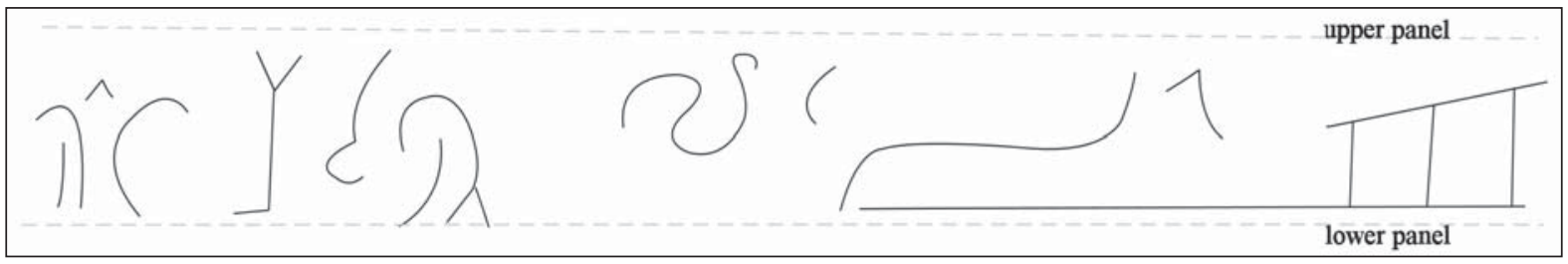

Figure 11. Decorative elements on an engraved compound bowl from the W. L. Willeford Farm site. 
SITE NAME OR SITE NUMBER: W. L. Willeford Farm

VESSEL NO.: UR5-13

VESSEL FORM: Carinated bowl

NON-PLASTICS AND PASTE: grog

RIM AND LIP FORM: Inverted rim and a rounded, exterior folded lip

CORE COLOR: B (fired and cooled in a reducing environment)

INTERIOR SURFACE COLOR: dark grayish-brown

EXTERIOR SURFACE COLOR: dark grayish-brown; fire clouds on the rim and body

WALL THICKNESS (IN MM): rim, $6.0 \mathrm{~mm}$

INTERIOR SURFACE TREATMENT: smoothed

EXTERIOR SURFACE TREATMENT: burnished

HEIGHT (IN CM): 5.5

ORIFICE DIAMETER (IN CM): 8.0

DIAMETER AT BOTTOM OF RIM OR NECK (IN CM): 10.0

BASE DIAMETER (IN CM) AND SHAPE OF BASE: 5.5; circular and flat

ESTIMATED VOLUME (IN LITERS): 0.26

DECORATION (INCLUDING MOTIF AND ELEMENTS WHEN APPARENT): The rim panel is divided into four sections divided by five vertical engraved brackets; the brackets have a single central diagonal line across them (Figure 12). Within each section are horizontal scrolls with either upwards or downwardsturning ends. One section has two separate horizontal scrolls instead of one. Above and below each of the scrolls are linear tick marks, rather than the excised pendant triangles of Ripley Engraved, var. McKinneyEnis Smith (Fields et al. 2014:Table 8.6), but the decorative effect is the same.

PIGMENT USE AND LOCATION ON VESSEL: None

TYPE AND VARIETY (IF KNOWN): Ripley Engraved, var. McKinney-Enis Smith

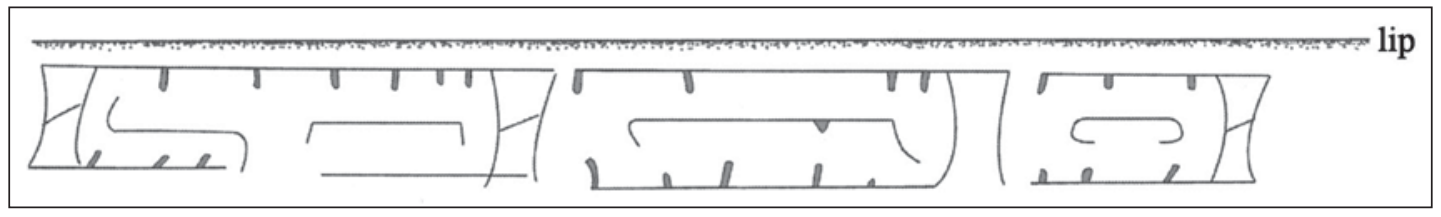

Figure 12. Decorative elements on Ripley Engraved, var. McKinney-Enis Smith Carinated bowl from the W. L. Willeford Farm site. 
SITE NAME OR SITE NUMBER: W. L. Willeford Farm

VESSEL NO.: UR5-14

VESSEL FORM: Carinated bowl

NON-PLASTICS AND PASTE: grog

RIM AND LIP FORM: Direct rim and rounded, exterior folded lip

CORE COLOR: F (fired in a reducing environment and cooled in the open air)

INTERIOR SURFACE COLOR: brown; fire clouds on the rim, body, and base

EXTERIOR SURFACE COLOR: brown; fire clouds on the rim, body, and base

WALL THICKNESS (IN MM): rim, $4.9 \mathrm{~mm}$

INTERIOR SURFACE TREATMENT: smoothed

EXTERIOR SURFACE TREATMENT: burnished

HEIGHT (IN CM): 4.0

ORIFICE DIAMETER (IN CM): 10.3

DIAMETER AT BOTTOM OF RIM OR NECK (IN CM): 9.8

BASE DIAMETER (IN CM) AND SHAPE OF BASE: 3.5; circular and flat

ESTIMATED VOLUME (IN LITERS): 0.25

DECORATION (INCLUDING MOTIF AND ELEMENTS WHEN APPARENT): The rim panel is defined by single upper and lower horizontal engraved lines. The panel is divided into four sections by excised brackets (Figure 13). Each section has a single horizontal scroll with rounded scroll ends. Above and below each of the horizontal scrolls are a series of small excised pendant triangles. The vessel also has a single horizontal engraved line on the interior at the carination.

PIGMENT USE AND LOCATION ON VESSEL: None

TYPE AND VARIETY (IF KNOWN): Ripley Engraved, var. McKinney-Enis Smith

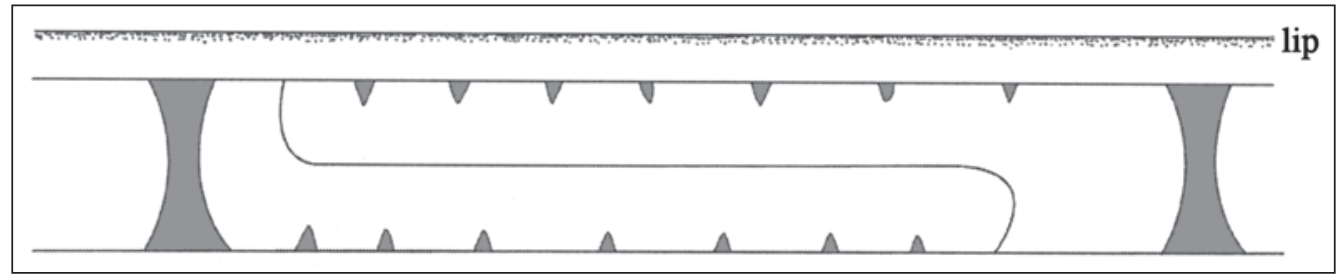

Figure 13. Decorative elements on Ripley Engraved, var. McKinney-Enis Smith carinated bowl from the W. L. Willeford Farm site. 
SITE NAME OR SITE NUMBER: W. L. Willeford Farm

VESSEL NO.: UR5-15

VESSEL FORM: Bottle with a globular body and a slightly expanding neck

NON-PLASTICS AND PASTE: grog

RIM AND LIP FORM: Direct rim and rounded lip

CORE COLOR: $\mathrm{G}$ (fired in a reducing environment and cooled in the open air)

INTERIOR SURFACE COLOR: dark grayish-brown

EXTERIOR SURFACE COLOR: yellowish-brown; fire clouds on the neck, body, and base

WALL THICKNESS (IN MM): rim, $4.8 \mathrm{~mm}$

INTERIOR SURFACE TREATMENT: none

EXTERIOR SURFACE

TREATMENT: smoothed

HEIGHT (IN CM): 11.5

ORIFICE DIAMETER

(IN CM): 4.0

DIAMETER AT

BOTTOM OF RIM OR

NECK (IN CM): 4.3;

maximum body diameter is $7.8 \mathrm{~cm}$

BASE DIAMETER (IN CM) AND SHAPE OF

BASE: 5.7; circular and flat

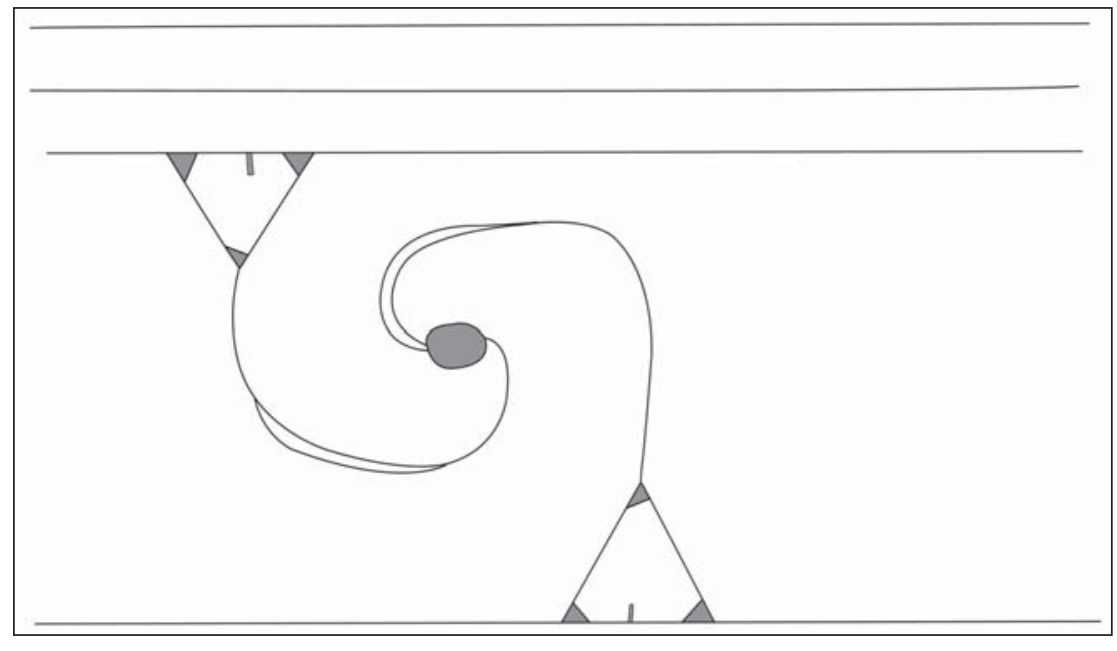

Figure 14. Decorative elements on Wilder Engraved, var. Wilder bottle from the W. L. Willeford Farm site.

ESTIMATED VOLUME (IN LITERS): 0.26

DECORATION (INCLUDING MOTIF AND ELEMENTS WHEN APPARENT): The vessel body has three horizontal engraved lines below the bottle neck and two horizontal engraved lines above the vessel base. The panel between them has four sets of upper and lower scrolls that curve around each other and meet at a small excised circle (Figure 14). The scroll portions on either side of the excised circle are wider because of the addition of a second engraved scroll line. The scrolls originate at upper and lower pendant triangles that have excised corners and a dashed line along the bottom edge of each triangle.

PIGMENT USE AND LOCATION ON VESSEL: None

TYPE AND VARIETY (IF KNOWN): Wilder Engraved, var. Wilder 
SITE NAME OR SITE NUMBER: W. L. Willeford Farm

VESSEL NO.: UR5-Extra-1

VESSEL FORM: Jar

NON-PLASTICS AND PASTE: grog

RIM AND LIP FORM: Everted rim and rounded lip

CORE COLOR: B (fired and cooled in a reducing environment)

INTERIOR SURFACE COLOR: black; organic residue on the rim

EXTERIOR SURFACE COLOR: black

WALL THICKNESS (IN MM): rim, $5.5 \mathrm{~mm}$; body, $6.5 \mathrm{~mm}$

INTERIOR SURFACE TREATMENT: smoothed

EXTERIOR SURFACE

TREATMENT: none

HEIGHT (IN CM): rim

height, $5.7 \mathrm{~cm}$

ORIFICE DIAMETER (IN

$\mathrm{CM}): 27.0$

DIAMETER AT BOTTOM

OF RIM OR NECK (IN

CM): 26.8

BASE DIAMETER (IN

CM) AND SHAPE OF

BASE: N/A

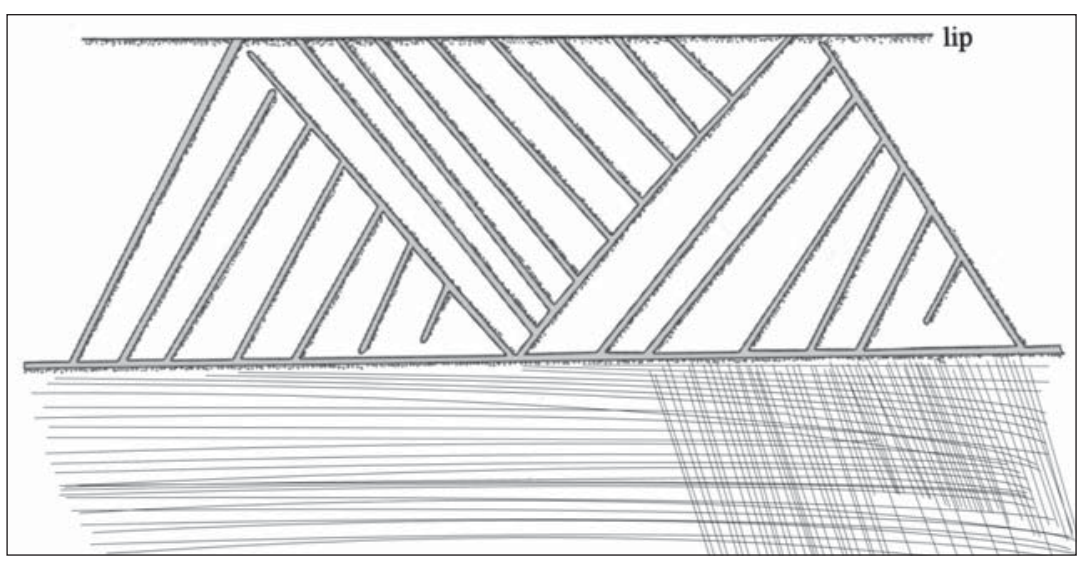

Figure 15. Decorative elements on Maydelle Incised jar from the W. L. Willeford Farm site.

ESTIMATED VOLUME

(IN LITERS): N/A

DECORATION (INCLUDING MOTIF AND ELEMENTS WHEN APPARENT): The rim has a continuous series of diagonal opposed incised lines that form alternating triangle elements (Figure 15). The vessel body has parallel and overlapping brushing marks.

PIGMENT USE AND LOCATION ON VESSEL: None

TYPE AND VARIETY (IF KNOWN): Maydelle Incised 


\section{SUMMARY AND CONCLUSIONS}

The W. L. Willeford Farm site (41UR5) in the Little Cypress Creek basin in East Texas is a Late Caddo period Titus phase settlement with a small cemetery. Vessels from the cemetery were obtained by the landowner around 1930, and University of Texas (UT) archaeologists purchased the collection in 1931. Excavations by UT recovered habitation debris (primarily plain and decorated ceramic sherds) and did not identify any ancestral Caddo burial features.

The 15 ceramic vessels from the site are all tempered with grog, which is consistent with other Caddo vessel assemblages in the Big and Little Cypress Creek basins. The vessel forms represented in the assemblage include bottles $(n=2)$, carinated bowls $(n=5)$, compound bowl $(n=1)$, bowl $(n=1)$, jars $(n=5)$, and a unique conjoined carinated bowl-jar. Fine ware types identified in the vessels are Bailey Engraved, Ripley Engraved (var. McKinney and var. McKinney-Enis Smith), and Wilder Engraved (var. Wilder and var. unspecified). Identified utility ware types at the W. L. Willeford site are Harleton Appliqued and Maydelle Incised. The common occurrence of Ripley Engraved, var. McKinney and var. McKinney-Enis Smith suggests that the burial features at the site likely date to the latter part of the Titus phase, after ca. A.D. 1550.

\section{ACKNOWLEDGMENTS}

We thank Mary Beth Tomka and Jonathan Jarvis of the Texas Archeological Research Laboratory at The University of Texas at Austin and Robert Cast, the Tribal Historic Preservation Office at the time of the Caddo Nation of Oklahoma, for access to the W. L. Willeford Farm site vessel collections. Lance Trask prepared the figures in this article.

\section{REFERENCES CITED}

Fields, R. C., V. L. Hatfield, D. Burden, E. F. Gadus, M. C. Wilder, and K. W. Kibler

2014 Testing and Data Recovery Excavations at 11 Native American Archeological Sites along the U.S. Highway 271 Mount Pleasant relief Route, Titus County, Texas. 2 Vols. Reports of Investigations No. 168. Prewitt and Associates, Inc., Austin.

Suhm, D. A. and E. B. Jelks (editors)

1962 Handbook of Texas Archeology: Type Descriptions. Special Publication No. 1, Texas Archeological Society, and Bulletin No. 4, Texas Memorial Museum, Austin. Reprinted in 2009, Gustav's Library, Davenport, Iowa. 